\title{
EVERY ADOLESCENT DESERVES A PARENT
}

DALE MARGOLIN*

\section{INTRODUCTION}

My twenty-year old client, Leo, ${ }^{1}$ needed a parent-not a mentor, a big brother, a best friend, or a tutor, although he would have welcomed those as well. Leo was approaching the age when he would be released from foster care and on his own, so we brainstormed about resources to help with the transition. He mentioned that he was extremely close to a friend's father. "I know he cares about me a lot," Leo told me. "Actually, he has said he loves me. But he is still just someone else's dad. If I mess up, he feels bad, but it doesn't really matter to him. His life is not tied to mine."

In one stream of consciousness, Leo summarized why so many "permanency plans" for adolescents are not permanent at all and why adoptions of older children can be unstable. There is a difference between a resource and a parent. ${ }^{2}$ Although a parent does not have to be biological or adoptive, ${ }^{3}$ a parent must have a stake in the child. ${ }^{4}$

This article argues that all adolescents, indeed all human beings, deserve at least one parent - one person who takes the good with the bad because that person's life is intertwined with the child's. The child matters to the parent in a way that a friend, nephew, or foster child may not. Child welfare professionals must never lose sight of this principle when they recruit, train, and maintain parents for adolescents. The parent can be

Copyright (C) 2012, Dale Margolin.

* Associate Clinical Professor of Law, Director, Family Law Clinic, University of Richmond School of Law. The author would like to thank Elizabeth Harding for her invaluable research assistance.

${ }^{1}$ References to particular clients are derived from personal contact with the author.

2 See Gary R. Anderson, Mich. State Univ., Aging Out of the Foster Care System: Challenges And Opportunities for the State of Michigan 32 (2003), available at $\mathrm{http} / /$ www.ippsr.msu.edu/publications/ARFosterCare.pdf (noting that various outside supports and services cannot replace the benefit one receives from being part of a "nurturing family and community").

${ }^{3}$ See id. at 7 ("[T] he presence of caring adults, be they formal or informal mentors, former foster parents or biological relatives, provides...y youth[s] with information, encouragement, and the impetus to become self-sufficient.").

${ }^{4}$ Adopting a Foster Child, PARENTS, http:/www.parents.com/parenting/adoption/facts/ adopting-a-foster-child/ (last visited Oct. 15, 2011). 
someone who is already in the young person's life or someone who has been unable to parent in the past, but is now ready to secure that bond. True parents are attainable for teenagers in foster care as long as child welfare professionals remember what they are looking for and are steadfast and creative in their efforts to find and nurture these relationships.

Section Two of this article details the issues that adolescents face when they age out ${ }^{5}$ of the foster care system. Next, Section Three discusses the obstacles adolescents face in attaining familial permanency. Section Four examines the aspects of successful adoptions, including the recruitment and decision making processes, in an effort to apply those principals to developing and maintaining adolescent permanency. Finally, Section Five concludes with the keys to successful adolescent permanency.

\section{The Plight of Adolescents Who Age Out of Foster CAre}

In the last decade, federal and state governments have paid increasing attention to older youth in foster care, in particular those who are discharged to themselves. ${ }^{6}$ Under both federal and state legislation, agencies are expected to favor reunifying teenagers with their biological families or securing adoptions for them prior to release from foster care. ${ }^{7}$ In reality, the permanency goal for most young adults is "another permanent planned living arrangement" (APPLA), previously known as "independent living," which essentially means that youth are released from the system to live on their own. ${ }^{8}$

\footnotetext{
${ }^{5}$ A young person "ages out" of foster care when the state ceases to retain legal custody because of the youth's age. The youth is discharged from the system, and the state ends financial support. The youth is released to his or herself, not to another custodian. In most states, aging out occurs at age eighteen. See Aging Out, St. N.M. Child. Youth \& Fam. DEP'T, http://www.cyfd.org/content/aging-out (last visited Mar. 23, 2012).

${ }^{6}$ See, e.g., Anderson, supra note 2, at 23 (discussing the John H. Chafee Foster Care Independence Program, a federal law providing states with funding to establish programs that assist former foster care recipients between ages nineteen and twenty-one in making the transition from adolescence to adulthood and in achieving self-sufficiency).

7 See 42 U.S.C. §671(a)(15)(B) (2006); 42 U.S.C. §675(1)(E) (2006); LaShanda Taylor, Resurrecting Parents of Legal Orphans: Un-Terminating Parental Rights, 17 VA. J. Soc. POL'Y \& L. 318, 322-24 (2010).

${ }^{8}$ See Sarah Gerstenzang, Mama S \& Papa M: Making APPLAs Work for Youth, Fostering FAMILIES TODAY, May/June 2010, at 56, available at http://nysccc.org/wpcontent/uploads/APPLA.pdf; PAt O'Brien, Youth Homelessness and the LACK of Adoptive and Other Permanent Parental Planning for Teens in Foster Care: Preventing Homelessness Through Parenting 2, available at http://www.judiciary.
}

(continued) 
According to the federal government's most recent statistics, there are approximately 423,773 children in foster care in the United States, almost half of whom are age eleven or older. ${ }^{9}$ These older children are far less likely to be adopted; they are also less likely to be placed in a foster family home or with a relative, which is considered ideal for reducing the trauma of removal. ${ }^{10}$ Thirty-six percent of all foster youth ages sixteen and older are currently living in group homes or institutions. ${ }^{11}$ Countless studies find that children raised in institutions "are at a higher risk of developing physical, behavioral, or emotional problems that ultimately can lead to negative outcomes." 12

Youth in group settings rarely find a permanent home compared to those living with foster families, and the longer they wait, the more difficult it becomes. ${ }^{13}$ An adolescent is thirty-three times more likely to remain in foster care for the rest of the adolescent's youth than a preschooler. ${ }^{14}$ According to official records, over twenty thousand youth age out each year, but this number does not count the tens of thousands

state.nj.us/conferences/1A-7/ELECTRONIC\%20\%20YOUTH\%20HOMELESSNESS\%20\%20Update\%202008.pdf (last visited Nov. 22, 2011).

9 Children's Bureau, U.S. Dep't of Health and Hum. Servs., The AFCARS RePORT: PreliminARy FY 2009 Estimates AS OF July 20101 (2010), available at http://www.acf.hhs.gov/programs/cb/stats_research/afcars/tar/report17.pdf.

${ }^{10}$ Ada Schmidt-Tieszen \& Thomas P. McDonald, Children Who Wait: Long-Term Foster Care or Adoption?, 20 CHILD. \& Youth SERV. ReV. 13, 23-24 (1998) (finding that older children are less likely to be adopted); RichARD WERTHEIMER, CHILD TRENDS Research Brief, Youth Who “Age Out” of Foster Care: Troubled Lives, Troubling PROSPECTS 4 (2002), available at http://www.childtrends.org/files/FosterCareRB.pdf (noting that older children are substantially less likely to live in a foster family and to be adopted); Andrew Atwal, Children in Foster Care Down 22 Percent in Decade, Youth TODAY (May 31, 2011), http://www.youthtoday.org/view_article.cfm?article_id=4814 (reporting that children sixteen years and older are less likely than children ages one to five to be placed with a relative); Kids Count, The Annie E. Casey Found., Data Snapshot on Foster Care Placement, Moving in the Right Direction: More Kids in Families 1 (2011), available at http://www.aecf.org/ /media/Pubs/Initiatives/KIDS\%20COUNT/D/

DataSnapshotFosterCarePlcmnt/DataSnapshot_FinalWeb.pdf ("Most experts believe that placing children with relatives or other caregivers they already know reduces the inevitable trauma of being removed from their parental homes.").

${ }^{11}$ Atwal, supra note 10.

${ }^{12} I d$.

${ }^{13}$ See Schmidt-Tieszen \& McDonald, supra note 10, at 24.

${ }^{14} I d$. 
who run away. ${ }^{15}$ The majority of these adolescents are legal orphans; their parents' rights were terminated while they were in foster care, and they were never adopted. ${ }^{16}$ The lack of a legal parent can itself be psychologically damaging. ${ }^{17}$ Even more significantly, too many teenagers are missing the parental figures and human support systems that most take for granted.

Not surprisingly, the outcomes are grim. Some young people go directly from a group or foster family home to homelessness. Even those who stay with their family, foster family, or friends have unstable housing for at least eighteen months after discharge and often for the rest of their lives. ${ }^{18}$ Specifically, research on young adults in homeless shelters by the National Association of Social Workers (NASW) indicates "that $38 \%$ of the youths surveyed had been in foster care at some time during the previous year alone. An additional $11 \%$ had arrived from another runaway or crisis shelter accounting for a total of $49 \%$ coming from some out-ofhome facility in the previous year...."19 Less than $50 \%$ of youth who age out of foster care have a high school diploma, and fewer than $1 \%$ go on to

15 Youth “Aging Out” of Foster Care, NAT'L Foster CARE COAL., http://www. nationalfostercare.org/facts/youthagingout.php (last visited Nov. 4, 2011) ("Each year, an estimated 25,000 young people 'age out' of the U.S. foster care system."). See also MARK E. Courtney et al., Chapin Hall Ctr. for Children at the Univ. of Chi., Midwest Evaluation of the Adult Functioning of Former Foster Youth: Outcomes AT Age 21 6-7 (2007), available at http://www.chapinhall.org/sites/default/files/ChapinHallDocu ment_2.pdf (conducting a study on the outcomes for youth who age out of foster care and noting that the study sample did not include youth who ran away or were otherwise missing from their placement); The NewsHour with Jim Lehrer: Aging Out of Foster Care (PBS television broadcast May 19, 2005), transcript available at http://www.pbs.org/newshour/bb/youth/jan-june05/foster_care_5-19.html) ("While there are 30,000 foster kids who age out annually, there are another 30,000 who are simply dropped from state care because they've run away.").

${ }^{16}$ See Taylor, supra note 7, at 321, 324.

${ }^{17}$ See id. at 328-29.

${ }^{18}$ See id. at 328 ("[C]hildren who age out of the foster care system without permanent homes or legal connections experience dire outcomes in an array of well-being indicators, including homelessness....”); Housing and Homelessness: Publications and Reports, Child Welfare LeAGUE AM., http://www.cwla.org/programs/housing/housingpubspage.h tm (last visited Oct. 16, 2011) (noting that $25 \%$ of youth previously in foster care reported being homeless on at least one night within 2.5-4 years after exiting foster care and that $34 \%$ of Wisconsin youth previously in foster care reported being homeless or living in four or more places within twelve to eighteen months after exiting foster care).

${ }^{19}$ O'BRIEN, supra note 8 , at 1 . 
finish college. ${ }^{20}$ Close to $27 \%$ of all males are incarcerated shortly after aging out, ${ }^{21}$ and nearly half of the young women become pregnant. ${ }^{22}$ Social isolation is the norm. ${ }^{23}$

To better prepare young people in foster care for adulthood, laws now require that young people be offered independent living services, regardless of their permanency goal. ${ }^{24}$ These laws also require a written independent living plan with provisions for housing, employment, public benefits, health care, and normalizing immigration status, when necessary. ${ }^{25}$ However, no matter how effective youth and their advocates are at obtaining documents, filing benefit applications, and securing housing, education, jobs, and credit, none of this is the equivalent of human connections. In addition to completing these tasks, child welfare professionals must connect all foster youth with at least one person who can have a parental relationship with them.

In fact, at least $25 \%$ of youth who age out return to live with their family of origin, and many more maintain other contact with their family for the rest of their lives, ${ }^{26}$ as well they should. Regardless of the agency's reasons for initially removing the child, youth who find members of their families or adult friends from their past do better than those who try to

\footnotetext{
${ }^{20}$ Honoring Emancipated Youth, BARriers Facing Foster CARE Youth: NATIONAL AND Local Statistics About Emancipating Foster Youth 1 (2008), available at http://www.heysf.org/pdfs/HEYFosterYouthStatistics.pdf ("[F]ewer than 10\% of [those youth who age out of foster care and] graduate from high school enroll [in] college, and of those, less than $1 \%$ graduate from college.").

${ }^{21}$ The NewsHour with Jim Lehrer: Aging Out of Foster Care, supra note 15.

${ }^{22}$ See Lucy A. Bilaver \& Mark E. Courtney, Nat'l Campaign to Prevent Teen Pregnancy, Science Says Research Brief No. 27, Foster Care Youth 2 (2006), available at http://www.thenationalcampaign.org/resources/pdf/SS/SS27_FosterCare.pdf.

${ }^{23}$ See, e.g., Susan Kools \& Christine Kennedy, Foster Child Health and Development: Implications for Primary Care, 29 PediAtric Nursing 39, $44 \quad$ (2003) (“Adolescents . . . reported feeling stigmatized by peers for their diminished status of foster child, resulting in social isolation.”).

${ }^{24}$ See 42 U.S.C. § 677(h) (2006); Independent Living, ChILD WELFARE INFO. GATEWAY, http://www.childwelfare.gov/outofhome/independent/ (last visited Oct. 6, 2011).

${ }^{25}$ For a complete explanation of the services and professional advocacy relevant to independent living law, see Dale Margolin, Clients Aging Out of Care, 12 CHILDREN's Rights 1, 1, 10-15 (2009).

${ }^{26}$ CouRTNEY ET AL., supra note 15, at 20.
} 
make a life on their own. ${ }^{27}$ Study after study confirms that human connection is the key to resilience at all stages of life. ${ }^{28}$

\section{UNIQUE ASPECTS OF ADOPTION AND FAMILY PERMANENCY FOR ADOLESCENTS}

Adopting or forming a parental bond with an adolescent is different from adopting a child of any other age. ${ }^{29}$ There are historic, institutional, and psychological hurdles to overcome. ${ }^{30}$ Landsman et al. identify five major obstacles that make it more difficult to secure permanence for adolescents. ${ }^{31}$ However, none of these factors precludes the discovery and maintenance of parental relationships and homes for adolescents.

The first obstacle is that, throughout the history of foster care, adolescents have been considered "unadoptable" by social service professionals. $^{32}$ The perception is that at their developmental stage, adolescents want and need independence and are incapable of forming attachments. ${ }^{33}$ These notions are wrong. Young people in foster care are especially adept at bonding - otherwise they could not have survived their traumas. $^{34}$ Further, people of all ages are able to create new, healthy

${ }^{27}$ See id.

28 See Wendy L. Haight et al., Understanding and Supporting Parent-Child Relationships During Foster Care Visits: Attachment Theory and Research, 48 Soc. WorK 195, 197-98 (2003).

${ }^{29}$ See generally Miriam J. LANDSMan et al., Nat'L Resource Ctr. For Family Centered Practice, The Prevention Report No. 2, Achieving Permanency for Teens: Lessons LeARned From a Demonstration Project 14 (1999), available at http://www.uiowa.edu/\%7Enrcfcp/publications/documents/Fall1999.pdf.

${ }^{30}$ See generally id.

${ }^{31} \mathrm{Id}$. at $14-15$.

${ }^{32}$ See id.; Kristi Charles \& Jennifer Nelson, Nat'l Resource Center for Youth Development, Permanency Planning: Creating Life long Connections, What Does It MEAN FOR AdOLESCENTS? 15 (2002), available at http://www.eric.ed.gov/PDFS/ED4787 88.pdf.

${ }^{33}$ See LANDSMAN ET AL., supra note 29, at 14-15; ChARLES \& Nelson, supra note 32, at 14-15.

${ }^{34}$ See generally LANDSMAN ET AL., supra note 29, at 14-15. See also CHARLES \& NELSON, supra note 32, at 13-14 ("A resilient child is one who bounces back from adversity and continues to function reasonably well despite continued exposure to risk .... Studies have demonstrated that attachment to a supportive adult, related or unrelated, can be one of the key variables correlated with resilience."); Rose MARIE WENTZ, NAT'L RES. CTR. for Family-Centered Practice and Permanency Planning at the Hunter Coll. Sch. of Social Work, Visitation-The Key to Children's Safety, Permanency and Well- 
attachments as well as build on prior ones. ${ }^{35}$ Family and security are just as necessary to a young adult as physical touch is to a newborn. ${ }^{36}$

Older children in foster care may be very vocal in their resistance or concerns about family permanence or adoption. ${ }^{37}$ This is wholly understandable considering the instability they have experienced. If people from all walks of life fear rejection, ${ }^{38}$ how could one expect anything else from children removed from their families and bounced from strangers' homes to institutions? These sentiments must never be discounted or minimized. Instead, social workers and lawyers should acknowledge and address them. For too long child welfare professionals have taken this resistance literally and allowed it to end efforts at family permanency. ${ }^{39}$ Teenagers desire and require unconditional love, just like every other individual. $^{40}$

BEING 2 (2011) ("Children are more resilient when they have multiple healthy connections. Resiliency is the key to surviving trauma."); Haight et al., supra note 28, at 197 (“[P]ositive experiences, such as the development of a positive attachment relationship with a foster parent or therapy, may partially correct the effects of early neglect or trauma.").

${ }^{35}$ See LANDSMAN ET AL., supra note 29, at 14-15; Charles \& Nelson, supra note 32, at $13-16$.

36 See Charles \& Nelson, supra note 32, at 16 (discussing a child's need for meaningful, lifelong relationships and the likelihood that a child will move on to an unstable adulthood and be at risk for long-term emotional and social problems without those relationships); Katherine Harmon, How Important Is Physical Contact for Your Infant?, ScI. AM., May 6, 2010, available at http://www.scientificamerican.com/article.cfm ?id=infant-touch ("Many children who have not had ample physical and emotional attention are at higher risk for behavioral, emotional and social problems as they grow up.”).

${ }^{37}$ See Charles \& Nelson, supra note 32, at 14.

38 See, e.g., David A. Hoffman, Mediation, Multiple Minds, and Managing the Negotiation Within, 16 HaR. NeGOT. L. Rev. 297, 314-15 (2011) (discussing the Internal Family Systems Model, a theory postulating that all individuals have internal parts which interact with one another in the individual's daily life when, for example, they are apprehensive to take chances at work or in love due to fear of rejection); Emily J. Carson, Off the Record: Why the EEOC Should Change Its Guidelines Regarding Employers' Consideration of Employees' Criminal Records During the Hiring Process, 36 J. CoRP. L. 221, 233 (2010) (noting that individuals with prior convictions may fail to apply for a job due to a fear of rejection).

${ }^{39}$ See ChARLES \& Nelson, supra note 32 , at 14-15.

${ }^{40}$ See id. at 7 (noting the necessity of maintaining the health, safety, and well-being of each individual member of a family unit, including both parents and children). 
Further, federal legislation is the second obstacle to achieving family permanency for adolescents. ${ }^{41}$ Although recent laws mandate independent living services, they do not specifically require or hold agencies accountable for finding and fostering human relationships. ${ }^{42}$ The caseworkers at most agencies are recruited to work with younger children. If they receive any adolescent training at all, it invariably focuses on how to teach independent living skills. ${ }^{43}$ Furthermore, the Adoption and Safe Families Act ${ }^{44}$ (ASFA) time frames put all the emphasis on the early stages of a child's time in placement; after a young person's first twenty-two months in care, the deadlines to achieve permanency cease. ${ }^{45}$

The third obstacle is the apparent lack of families that are willing to adopt or unconditionally love teenagers. ${ }^{46}$ The dearth exists because social service professionals have not made specialized efforts to recruit and educate families about forming long-term relationships with adolescents. ${ }^{47}$ However, the numbers belie the truth: there are people willing to share their lives with young adults if given the opportunity to connect with them. ${ }^{48}$ Believing that teenagers are unadoptable on both ends, caseworkers also worry that permanent family placements will fail. ${ }^{49}$ Not every story will be a success. ${ }^{50}$ The difficulties that children and their caregivers experience should teach child welfare professionals how to support them, not prevent the professionals from trying at all.

${ }^{41}$ See LANDSMAN ET AL., supra note 29, at 15; ChARLES \& NELSON, supra note 32 (discussing the second barrier to permanency identified by Landsman et al., and noting that the Adoption and Safe Families Act negatively impacted the achievement of permanency for adolescents); Dale Margolin, Seeking Shelter in Tough Times: Securing Housing for Youth Who Age Out of Foster Care, 27 CHILd L. PraC. 65, 65, 70 (2008) (noting the deficiencies in the Chafee Foster Care Independent Living Program).

${ }^{42}$ See 42 U.S.C. $\$ 671(a)(15)(B)$ (2006) (stating that only reasonable efforts must be made to preserve families); 42 U.S.C. $§ 675$ (1)(E) (2006); Margolin, supra note 41, at 65.

${ }^{43}$ See Charles \& Nelson, supra note 32 , at 15.

${ }^{44}$ Adoption and Safe Families Act, 42 U.S.C $§ \S 620-679$ (2006).

${ }^{45} I d$. at $\S 675(5)$.

${ }^{46}$ LANDSMAN ET AL., supra note 29, at 15; CHARLES \& NELSON, supra note 32.

${ }^{47}$ LANDSMAN ET AL., supra note 29, at 15; ChARLES \& NELSON, supra note 32.

${ }^{48}$ Charles \& Nelson, supra note 32 , at 15-16.

${ }^{49}$ LANDSMAN ET AL., supra note 29, at 15; ChARLES \& Nelson, supra note 32.

50 LANDSMAN ET AL., supra note 29 (discussing the difficulties associated with achieving permanency for older children and noting that there is an approximate $10 \%$ disruption rate when adoption is the permanency goal for older children). 
A fourth obstacle is that the very people who already love and care for a particular child are left out of the permanency process. ${ }^{51}$ The child may be asked if the child "wants to be adopted," and if the child responds "no," the questions end there. ${ }^{52}$ Instead, child welfare professionals should talk to the young person about teachers, coaches, godparents, and neighbors. ${ }^{53}$ The child's teacher may not necessarily adopt him, but the teacher may have valuable information about other close relationships or ways of bonding with the child. ${ }^{54}$ The young person should be encouraged to invite confidants to the planning meetings. ${ }^{55}$ Although this is allowed under the law, it is not encouraged in practice. ${ }^{56}$

The final obstacle to adolescent permanency is a lack of programming and fiscal support. ${ }^{57}$ In recent years, state and local agencies have tried to redirect efforts and financial support away from the group home setting. Initiatives such as Families for Teens in New York, For Keeps in Virginia, and Permanency for Teens Project in Iowa have challenged antiquated notions about the importance of families for older youth. ${ }^{58}$ These targeted campaigns have reduced the number of youths in group homes and helped them form and rebuild lasting relationships. ${ }^{59}$

\footnotetext{
${ }^{51}$ LANDSMAN ET AL., supra note 29, at 15; CHARLES \& NELSON, supra note 32, at 16.

${ }^{52}$ See Charles \& Nelson, supra note 32 , at 14-15.

${ }^{53}$ See LANDSMAN ET AL., supra note 29, at 15; ChARLES \& Nelson, supra note 32 , at 16.

${ }^{54}$ LANDSMAN ET AL., supra note 29, at 15 (noting the importance of including the child's significant others in the permanency planning process as those individuals are "critical resources" who can provide information and assist in creating and analyzing the most viable options for permanency); CHARLES \& NELSON, supra note 32, at 16.

${ }^{55}$ See Gerstenzang, supra note 8, at 58; ChARLES \& NELSON, supra note 32, at 16.

${ }^{56}$ See Gerstenzang, supra note 8, at 58; ChARLES \& NELSON, supra note 32, at 16.

${ }^{57}$ LANDSMAN ET AL., supra note 29, at 15; ChARLES \& NELSON, supra note 32, at 16.

58 See N.Y.C. Admin. for Children's Servs., PreParing Youth for Adulthood 6 (2006), available at http:/www.nyc.gov/html/acs/downloads/pdf/youth_for_adulthood.pdf; Voices for Va.'s Children, Foster CARe Reform in Virginia: A Place to Call Home 1 (2008), available at http://www.vakids.org/pubs/foster\%20care/Foster\%20Care $\% 20 \mathrm{in} \% 20$ Virginia-\%20A\%20Place\%20to\%20Call\%20Home.pdf; LANDSMAN ET AL., supra note 29.

${ }^{59}$ See, e.g., N. Am. COUnCIL ON AdOPTABle ChILDREN FOR THE ANNIE E. CASEY Found. Family to Family Initiative, A Family for Every Child: Strategies to Achieve Permanence for Older Foster Children ANd Youth 19 (2005), available at http://www.nacac.org/adoptalk/family_every_child.pdf ("Families for Teens guidelines have had a significant impact on ACS child welfare practice, especially on reducing the use of residential treatment and group care...."); Lessons Learned About Permanency for Teens, ADOPTION.COM, http://library.adoption.com/articles/lessons-learned-about-perman
} 
Family permanency and support do not necessarily mean legal adoption; a commitment of unconditional love can take many forms. ${ }^{60}$ Some young people do not want to be adopted because of the symbolic meaning; they are emotionally connected to their family of origin or do not want to insult or damage those relationships. ${ }^{61}$ These are all valid sentiments, and as noted earlier, families of origin remain important resources for housing, financial, and other support. ${ }^{62}$

Flexibility is crucial. Instead of looking the other way or outright condemning a young person's desire to contact the young person's family of origin, child welfare professionals should foster healthy, safe relationships. This process should begin while the young adult is still in care, regardless of their discharge goal, to pave the way for productive, lifelong support systems. Some advocates even propose that parental rights be restored in instances when a young adult makes an informed decision and the parent's past difficulties have been resolved or are irrelevant. ${ }^{63}$ At the very least, visiting plans with the biological family, no matter where they live, should be developed and tweaked according to the child's wishes and needs as the child matures.

Moreover, restoring these biological relationships does not have to affect the emotional or legal stability of the kin or non-kinship foster family. Due to the complexities facing children and caregivers, a majority

ency-for-teens.html (last visited Nov. 6, 2011) (noting that many Permanency for Teens Project participants found permanency through adoptions or through lasting connections in the form of long-term foster care placements or new relationships with lost family members).

${ }^{60}$ See generally LANDSMAN ET AL., supra note 29.

While adoption remains the preferred permanency option for many children this may not be a viable option for all children. Permanency, especially for older children nearing adulthood, needs to be reconceptualized to include a broader range of options-including connections with family and important adults in their lives, and longterm foster care - that meet the child's needs for life-long, meaningful connections to significant others.

Id. (internal citations omitted).

${ }^{61}$ Charles \& Nelson, supra note 32, at 15 (noting that there are several reasons youth may reject the idea of permanent placement or adoption, including loyalty to the youth's birth family).

${ }^{62}$ See Taylor, supra note 7, at 319-21.

${ }^{63}$ See, e.g., id. at 331-37. 
of states now offer some form of subsidized guardianship as an alternative to adoption. ${ }^{64}$

In cases where subsidized guardianship is not available, the child and caregiver want out of the system, and they are willing and able to forgo financial support from the state, custody is another option. ${ }^{65}$ This is, of course, unrealistic for most families unless private support services are expanded. ${ }^{66}$ The foster care system could also be less rigid about continuing to subsidize youth who are with permanent, committed caregivers. Why should the system rush young adults to discharge from foster care if they are thriving in their homes? Ending the foster care payments for a child is a shortsighted goal; instead, the system should do whatever is necessary to cultivate lifelong, committed relationships. The child welfare system will spend less money in the long run if it prevents a child from becoming homeless, jobless, incarcerated, or pregnant. ${ }^{67}$

Mindsets about adolescents must change. Young people should never leave foster care without at least one committed adult by their side, even if they do not live together. This will take a nationwide concerted effort, from federal law down to local caseworkers. Inevitably, people will ask whether it is worth it.

\section{What ChILD Welfare Professionals CAN LEARN FROM SUCCESSFUL FAMILIES}

The recent, scattered efforts at family permanency for teenagers have yet to be fully examined. ${ }^{68}$ Research on the adoption of younger children

\footnotetext{
${ }^{64}$ See Children's Def. Fund, States' Subsidized GuARdianship Laws at a Glance 2 (2004), available at http://cdf.childrensdefense.org/site/DocServer/guardianship_laws.pdf ?docID=544.

${ }^{65}$ See Taylor, supra note 7, at 339-41.

${ }^{66}$ See Generations United, GENERATIONS UnITED (2011), www.gu.org (providing helpful information from a national clearinghouse for intergenerational and other nontraditional families and the organizations that aid them).

${ }^{67}$ See Taylor, supra note 7, at 328-29 ("'[C]hildren who age out of the foster care system without permanent homes or legal connections experience dire outcomes in an array of well-being indicators, including homelessness, criminal involvement, ... reliance on public assistance ... high instances of poverty, [and] unemployment ....").

${ }^{68}$ See Cynthia Flynn et Al., Field-Initiated Research on Successful Adolescent ADOPTIONS, FINAL REPORT 1-2 (2004), available at http://centerforchildwelfare.fmhi.usf. $\mathrm{edu} / \mathrm{kb} / \mathrm{bppub} /$ SuccessfulAdolescentAdopt.pdf.
} 
finds that adoptees often thrive after foster care. ${ }^{69}$ With adolescent adoptions, however, attention focuses primarily on their failure and the reasons why they disrupt or dissolve. ${ }^{70}$

Only one study broke this mold. Psychologists at the University of South Carolina conducted in-depth interviews of fifty families (ninety-five individuals) who successfully adopted adolescents. ${ }^{71}$ Families could participate only if their experience met three criteria: the adoption proceeded to completion, the adoption had been maintained, and the families and children had generally positive feelings about the adoption. ${ }^{72}$ In addition, the psychologists surveyed the adoptees and determined that they had above average life satisfaction. ${ }^{73}$

Adoptions are lifelong, evolving relationships. ${ }^{74}$ They have distinct phases that the psychologists examined to find commonalities. ${ }^{75}$ The families had vastly different experiences at all points during their adoptions, but the study indicated that certain practices and philosophies increase the odds of a beneficial outcome. ${ }^{76}$

\section{A. Recruitment}

Surprisingly, nearly half the families studied in South Carolina had no prior intention of adopting. ${ }^{77}$ This is important because too few efforts are made to educate and recruit people who do not take the initiative to learn about, or are completely unaware of, the possibility of adopting older children. ${ }^{78}$ Volunteering with and fostering youth were primary paths to

\footnotetext{
${ }^{69}$ See Sharon Vandivere \& Karen Malm, Child Trends, \& Laura Radel, U.S. Dep't. of Health and Human Servs., Adoption USA: A Chartbook Based on the 2007 NATIONAL SURVEY OF ADOPTIVE PARENTS 6 (2009), available at http://aspe.hhs.gov/hsp/09/NSAP/chartbook/doc/chartbook.pdf.

${ }^{70}$ See FLYNN ET AL., supra note 68, at 2 ("While many studies have been conducted examining disruptions and dissolutions, none have focused on successful adolescent adoptions. Our study on successful adolescent adoptions was designed to begin to fill this gap in the research.").

${ }^{71} \mathrm{Id}$. at $2-4$.

${ }^{72} I d$. at 2.

${ }^{73} \mathrm{Id}$. at 73 .

74 See Deborah N. Silverstein \& Sharon Kaplan, Lifelong Issues in Adoption, ADOPTING.ORG, http://www.adopting.org/silveroze/html/lifelong_issues_in_adoption.html (last visited Nov. 5, 2011).

${ }^{75}$ FLYNN ET AL., supra note 68, at 8-52.

${ }^{76} I d$. at $74-75$.

${ }^{77}$ Id. at 9.

${ }^{78}$ See id. at 10.
} 
unplanned adoption, but chance encounters and events also led $20 \%$ of the families to adopt. ${ }^{79}$ The key is to be multifaceted in the approach to educating the entire community and in creating opportunities for children in foster care to interact with a variety of adults. Big Brothers Big Sisters events, community fairs, and church activities are just a few potential meeting places. ${ }^{80}$

Other studies that focus on recruitment and training of unconditionally committed adults for adolescents find that if the adults know the young person in advance, they are five times more likely to follow through with the pre-placement process. ${ }^{81}$ This does not mean that the child must have a lifelong connection with the adult. Familiarity through an event or program is enough to vastly increase the odds. ${ }^{82}$ Where should the child welfare system start? First, it should ask the child about any individual, of any age, who is important to the child or whom the child remembers.

From there, child welfare professionals should seek the input of these familiar adults. Programs like Big Brothers Big Sisters should be a launching point, not a solution. A mentor can lead to unconditional commitment-whether by the mentor alone or through someone the mentor knows or has introduced the child to. All familiar adults should be invited to participate in planning meetings, if the child agrees. ${ }^{83}$ It may take years for these connections to lead to permanency, but child welfare professionals should make sure to invite all of the potential caregivers to the table.

\section{B. The Initial Decision to Adopt}

Of the families in the South Carolina study who knew they wanted to adopt, some wanted a child of any age because they could not have biological children; some were empty nesters or single parents specifically seeking a teenager; and many shared philosophical or religious convictions. ${ }^{84}$ The reasons for initiating adoption varied. ${ }^{85}$ Across the

\footnotetext{
${ }^{79}$ Id. at $9-10$.

${ }^{80}$ See id. at 10.

${ }^{81}$ Rosemary J. Avery, An Examination of Theory and Promising Practice for Achieving Permanency for Teens Before They Age Out of Foster Care, 32 CHILD. \& Youth Serv. REV. 399, 406 (2010).

${ }^{82} \mathrm{Id}$. at 404-06.

${ }^{83}$ See Gerstenzang, supra note 8, at 58; CHARLES \& NELSON, supra note 32, at 16.

${ }^{84}$ FLYNN ET AL., supra note 68 , at 8-9.

${ }^{85} \mathrm{Id}$. at $8-10$.
} 
spectrum, the decision to complete the adoption was a long process that was never made overnight. ${ }^{86}$

Even in the most streamlined and rare case-where a family knows they want to adopt, are willing to adopt a child of any gender or age, are quickly placed with a child, and decide to legally adopt the child - there will be challenges. ${ }^{87}$ Parents' commitment is continuously tested through an arduous bureaucratic, legal, and emotional journey. ${ }^{88}$

The child welfare system should make this process as smooth as possible. Every locality must have a centralized source of information about public adoptions, including information about children of all ages, how to access a wide variety of events, and details about the government's contract agencies.

Adults need time to understand and adjust their expectations for bonding with a young person. ${ }^{89}$ In the adolescent adoption study, it took most families months or years to "stretch." 90 They had to move at their own pace in finding and determining that adopting a particular child was right. ${ }^{91}$ The only time child welfare professionals should rule someone out as an unconditional resource is if they affirmatively state that they do not want to be part of the process or the child's life anymore. The prospective parents should be informed that, if it is appropriate for the child, the door is always open for the child to reconsider. All of the successful permanent relationships studied experienced at least some difficulties between the parent, child, or various professionals and agencies. ${ }^{92}$

\section{Pre-Adoption Placement and Services}

Before becoming an unconditional figure, the parents and child must be given time to get to know and attach to one other. Placement in the home should not be rushed. Families with the most successful adjustments to living together had longer visitation periods that they controlled, even if this meant starting and stopping the schedule when necessary. ${ }^{93}$

From day one, the adult must understand that the adult is becoming an unconditional figure in the adolescent's life. Every pre-placement training

\footnotetext{
${ }^{86}$ Id. at $12-15$.

${ }^{87}$ See id. at 15.

${ }^{88}$ See id.

${ }^{89}$ See generally id.

${ }^{90}$ See id.

${ }^{91}$ See id. at 12-15.

${ }^{92}$ Id. at $72-73$.

${ }^{93}$ See id. at 26.
} 
class should emphasize this. In fact, according to the Founder and Director of one of the most successful adolescent placement agencies in the country, You Gotta Believe (YGB), this is the only lesson that must be taught. ${ }^{94}$ The message in YGB's classes is reinforced by peer mentors who have gone through the process and now successfully parent a foster teen. ${ }^{95}$ Components of the adults' preparation also include ensuring that the adults both expect and accept rejection, before the teen even enters their home. ${ }^{96}$ The bottom line is that unconditional figures for adolescents must understand that they are making a commitment that is equivalent to becoming a biological parent - the relationship can never be undone. ${ }^{97}$ The adults may take their time and ultimately decide against it, but this is what every teenager needs and deserves.

\section{Finalizing the Decision to Adopt}

In the preceding stages, the emphasis is on the parents. They are the ones who decide to look for and bring a child in to their home. ${ }^{98}$ They are the ones who make the final decision to file the adoption. ${ }^{99}$ The judges and caseworkers determine what is in the child's "best interest" along the way. ${ }^{100}$ To be in the child's best interest, the child should understand and be a part of each step of the process. ${ }^{101}$ The child must be introduced to the subject of adoption on the child's time and must grow to accept the notion of adoption and the new family. ${ }^{102}$ Ultimately, whether required by law (as in a few states), or simply for the health of the family, the adolescent must consent to the adoption. ${ }^{103}$ Families should be creative, for example, by having the child choose the actual date of adoption, when the child is

${ }^{94}$ Telephone Interview with Pat O'Brien, Founder \& Executive Director, You Gotta Believe (Feb. 22, 2011) [hereinafter O'Brien Interview].

${ }^{95}$ Id. See also Avery, supra note 81, at 405.

${ }^{96}$ O’Brien Interview, supra note 94. See also Avery, supra note 81, at 405.

${ }^{97}$ See FLYNN ET AL., supra note 68, at 27, 72 (noting that adoption is a permanent commitment).

${ }^{98}$ Id. at $13-14$.

${ }^{99} \mathrm{Id}$. at 14,35 .

${ }^{100}$ See id. at 35 .

101 See Child Welfare League of Am., CWla Standards of Excellence for AdOPTION SERVICES 47 (2000).

102 See FLYNN ET AL., supra note 68, at 35.

103 See, e.g., VA. Code AnN. §63.2-1202 (2007 \& Supp. 2011) ("Consent shall be executed . . . by the child if he is 14 years of age or older, unless the circuit court finds that the best interests of the child will be served by not requiring such consent."). 
psychologically ready. ${ }^{104}$ Not only is this empowering but also it is reflective of the entire experience. The child's voice is integral from the moment permanency is discussed to the family's final meeting about postadoption services.

The importance of listening to the child is underscored by the fact that many of the successfully adopted children in the South Carolina study did not see their presence as a benefit to the family. ${ }^{105}$ Perhaps they had never felt loved or welcomed in any home. They could name dozens of reasons why being adopted helped them, ${ }^{106}$ but they had no idea that they could bring joy and gratification to their new family. Youth adrift in foster care are missing the most basic sense of security that the rest of society takes for granted. ${ }^{107}$ They believe they are a burden and must be persuaded otherwise. ${ }^{108}$ As one young man put it, "I needed to be convinced that the people who adopted me were not going to give me up like all the other foster homes and other people who said they wouldn't give me up and they did."109

It is crucial to add here that it is not the child's responsibility to be committed. "Normal" children do not have to demonstrate commitment to their parents, so why ask that of foster children? Although it will take work on the child's part, it is the parent who determines whether an adoption succeeds.

Linda Katz found that across the spectrum, the parental characteristics that stood out among healthy adoptive families include: "[a] tolerance for one's own ambivalence [or] strong negative feelings[;] . . . [a] refusal to be rejected by the child and an ability to ... delay gratification... [and] to postpone [the] rewards [of parenting] for a very long time[;] and [t]he ability of find happiness in small increments of improvement." 110 These families have a systemic view of the family, looking to understand

${ }^{104}$ See Child Welfare League of AM., supra note 101, at 47 ("The child . . . should be an active participant in planning for the adoption and should have an opportunity to express a choice to the fullest extent possible consistent with [the child's] age and developmental level.").

${ }^{105}$ FLYNN ET AL., supra note 68, at 40.

${ }^{106} \mathrm{Id}$. at 79.

${ }^{107}$ See Charles \& Nelson, supra note 32, at 12.

${ }^{108}$ See FLYNN ET AL., supra note 68, at 35.

${ }^{109} \mathrm{Id}$.

${ }^{110}$ Linda Katz, Parental Stress and Factors for Success in Older-Child Adoption, 65 Child Welfare 569, 574-75 (1986). 
problems as multifaceted instead of blaming or labeling one person. ${ }^{111}$ The family is open and seeks solutions from a wide range of resources. ${ }^{112}$ What this article calls unconditional commitment is reflected in Katz's term "firm entitlement": the parents take "full 'ownership' of the . . child in a short time [and] incorporat[e] the child's many differences and history comfortably." 113 Much of this is easier said than done, but these common qualities reiterate the potential of adolescent adoptions.

Despite popular belief about the difficulties of adopting older children, ${ }^{114}$ healthy relationships can be formed when parents have healthy attitudes. A study about adolescents in permanent guardianships demonstrated this. ${ }^{115}$ Surprisingly, teenagers with educational and behavioral difficulties were not harder to secure in permanent guardianships. ${ }^{116}$ As long as the guardian and child had a long-standing relationship, that bond solidified into a stable home for the child. ${ }^{117}$ In fact, the study also confirmed that guardianship - as opposed to adoption - may be the right choice for children who have strong emotional ties with their biological mothers but are unable live with them. ${ }^{118}$

Teenagers' prime responsibilities in becoming part of a permanent family then includes understanding the process, staying involved in the decision-making, and verifying that they feel loved unconditionally. The rest is in the parents' hands.

\section{E. Maintaining the Permanency}

Once a healthy bond is formed, it must be maintained. Here, adolescents do have an active role. A major cause of disruptions is running away, ${ }^{119}$ so child welfare professionals must help youth want to stay in their homes.

${ }^{111}$ Id. at 576 .

${ }^{112} \mathrm{Id}$. at 577.

${ }^{113} \mathrm{Id}$. at 576.

114 See Sonya J. Leathers et al., Predicting Family Reunification, Adoption, and Subsidized Guardianship Among Adolescents in Foster Care, 80 AM. J. ORTHOPSYCHIATRY 422, 423 (2010).

${ }^{115}$ See id. at 428-30.

${ }^{116} \mathrm{Id}$. at $427-28$.

${ }^{117}$ See id.

${ }^{118}$ See id. at 429.

${ }^{119}$ Pam Connell, When Adoptions Don 't Work Out, FAMILIES.COM, http://adoption.famil ies.com/blog/when-adoptions-dont-work-out\# (last visited Nov. 7, 2011). 
First, individual and group therapy for parent and child should begin before they even meet. Families report that effective counseling is both hard to find and unaffordable. ${ }^{120}$ However, specialized programs such as the Center for Adoption Support and Education (C.A.S.E.) now provide direct services as well training resources. ${ }^{121}$ C.A.S.E. was founded solely for adopted adolescents and their families. ${ }^{122}$ It operates on the principle that adoptees of all backgrounds and circumstances face unique issues during their childhood years. ${ }^{123}$ C.A.S.E. provides a safe place for young people to discover and accept themselves and mourn their losses. ${ }^{124}$ Parents learn techniques to handle common stumbling blocks. ${ }^{125}$ C.A.S.E. has demonstrated results in this area. ${ }^{126}$

A study of foster youth who chronically run away also found that interventions that are specifically tailored to a child's behavior are most effective for reducing elopement. ${ }^{127}$ First, "runners" were given a functional assessment to determine what motivated them to leave as opposed to what motivated them to stay. ${ }^{128}$ Then an individual plan was devised with the youth's input, which replicated the favorable circumstances, and found alternative solutions to the negative ones. ${ }^{129}$ The

${ }^{120}$ See Lisa Belkin, Talking in Depth About Adoption, Motherlode: AdVEnTURes in PARENTING (Apr. 13, 2010, 1:53 PM), http://parenting.blogs.nytimes.com/2010/04/13/

talking-in-depth-about-adoption/ ("The resources to help our children do not exist. The resources that do exist are overwhelmed .... It can be difficult to qualify your child for services .... Services are often unaffordable.”).

121 C.A.S.E. Training Program, CENTER FOR AdOPTION Support AND Educ., http://www.adoptionsupport.org/train/index.php (last visited Oct. 11, 2011).

${ }^{122}$ See About the Center for Adoption Support and Education, CENTER FOR ADOPTION SUPPORT AND EDUC., http://www.adoptionsupport.org/about/index.php (last visited Oct. 11, 2011).

${ }^{123}$ See id.

${ }^{124}$ Marilyn Schoettle \& Ellen Singer, Healing Loss in the Traumatized Child 2 (2004), available at http://www.adoptionsupport.org/pub/docs/HealingLossintheTraumatiz edChild04copyright.pdf.

${ }^{125}$ See Counseling and Support Services, CENTER For AdOPTION SupPort AND Educ., http://www.adoptionsupport.org/couns/index.php (last visited Nov. 7, 2011).

${ }^{126}$ See About the Center for Adoption Support and Education, supra note 122.

127 See Hewitt B. Clark et al., A Functional Approach to Reducing Runaway Behavior and Stabilizing Placements for Adolescents in Foster Care, 18 RES. ON SOC. Work PRAC. 429, 431 (2008).

${ }^{128} I d$. at $435-36$.

${ }^{129} I d$. at 436. 
youth was rewarded for not running with words of encouragement and an increase in privileges. ${ }^{130}$

Therapeutic and behavioral services should be supplemented with peer support groups for both parents and children. YGB implemented a Shadow Worker program, in which an adoptive parent is available for a new parent or newly placed teenager to call any time. ${ }^{131}$ The availability of respite care also gives peace of mind to families, although YGB reports that is rarely used. ${ }^{132}$ Instead, families may simply resolve issues on their own: they may allow the teenagers to try living with their biological relatives for a while, and let them return when they are ready.

In fact, $90 \%$ of the families in the South Carolina study did have contact with the biological family, and all were welcome to it. ${ }^{133}$ Families who adopt youth from foster care may want to "adopt the whole family,"134 meaning they accept and welcome healthy contact. Post adoption support should help families do this.

Financial resources must be allocated to developing appropriate services and enabling families to access them. Advocates agree that increasing adoption and guardianship subsidies would also help parents address educational and medical issues. ${ }^{135}$ Child welfare professionals cannot find permanent homes for adolescents unless they give their families the ability to thrive.

\section{The Keys to SuCCESS}

Four principles inform the current thinking and best practices for adolescents in foster care: (1) all young adults need at least one parental figure in their lives, but they have to find someone who is appropriate, and child welfare professionals must help them do this; (2) permanency only works if there is unconditional commitment to the adolescent by the parent; (3) the adolescent must understand and be part of the entire adoption and permanency process, and ultimately accept it; and (4) relationships formed between adults and adolescents are lifelong, and require ongoing emotional, community, and professional support.

${ }^{130} \mathrm{Id}$.

${ }^{131}$ O'Brien Interview, supra note 94. See also Avery, supra note 81, at 406.

${ }^{132}$ O'Brien Interview, supra note 94.

${ }^{133}$ FLYNN ET AL., supra note 68, at 53-54.

${ }^{134}$ See id. at 23.

${ }^{135}$ Cf. Richard P. Barth \& Devon Brooks, A Longitudinal Study of Family Structure and Size and Adoption Outcomes, 1 Adoption Q. 29, 53 (1997) ("[A]dopted children are a financial resource drain on families because families spend more than their subsidies.”). 